\title{
AIR DEFENSE IN A SPECIFIC ENVIRONMENT OF THE SUWALKI ISTHMUS
}

Karol SZYMANOWSKI, Lt. M.Sc.Eng.

$15^{\text {th }}$ Air Defense Regiment

k-szymanowski@wp.pl

\section{Abstract}

In the presented article the author desires to study requirements for the air defense subunits in the forest-lake environment of the Suwalki isthmus. For that purpose the author underlined the importance of the presented region, identified specifics of the isthmus, made a terrain analysis and defined the requirements of the air defense subunits operating in that area.

The submitted proposals learnt from the research indicate the need of use of the so-called light air defense in order to provide efficient defense for forces and critical infrastructure of the region. The author also takes into account the origin and presence of the Territorial Defense Forces air defense elements, drawing also attention to their place in the entire air defense system of the area and emphasizing the importance of the suitable armament selection for the newly formed air defense subunits of the Territorial Defense Forces (TDFs).

Keywords: air defense, Territorial Defense Forces, forest lake environment, light air defense

\section{INTRODUCTION}

Variable security environment in the Central and East Europe expressed inter alia by Russia's imperialist aspirations reinstated conversations concerning security of the Suwalki isthmus (earlier the Podlaska gate). The issue was addressed by the President of Estonia, Thomas Hendrik Ilves, who while referring to the issue of the Suwalki isthmus emphasizes the great importance and role of the Suwalki corridor in any potential NATO-Russia conflict: "During the Cold War there was a concept of the 'Fulda isthmus'. A place in the eastern Germany, where - in accordance with the planners' predictions - Russian tanks were to pass, in order to cross the Rhine and attack the West. The concept of NATO's planning was based on the defense of this isthmus. Today the city of Suwalki in Poland plays such a role, which is roughly the same size, as Fulda. This isthmus is situated about 70 kilometers between Belarus and the Kaliningrad Oblast. Only the border divides here Poland from Lithuania, then Latvia and Estonia, so if anyone wants to cut off the access to the three Baltic States, should pay close attention to the Suwalki isthmus."

In 2015 at the conference \#CEPAForum2015 operational plans were presented, and as it was expressed by the commander of the US Army in Europe, General Ben Hodges, there are three greatest hot spots in Europe:

- Suwalki isthmus (Suwalki corridor);

- Donbas;

- Turkish-Syrian border.

Referring to the Polish-Lithuanian border, General Hodges admitted that despite the creation of the Very High Readiness Task Force, which main purpose is to respond quickly in the event of a threat to a NATO member state's security, it may take up to two weeks to cross the border

1 Estonian President Toomas Hendrik Ilves referring to the issue of the Suwalki isthmus. See: M. Rachoń, „NATO ostrzega: Polska najbardziej zagrożonym rejonem po Donbasie”, Niezależna.pl 09.10.2015, retrieved from: http://niezalezna.pl/71738-nato-ostrzega-polska-najbardziej-zagrozonym-rejonem-po-donbasie, (02.05.2017); (own transl.). between Poland and Lithuania. ${ }^{2}$ When comparing the military capabilities of the Baltic States and the potential opponent, which might be Russia, NATO's two-week reaction time will certainly allow the Baltic States to become fully taken into control by the coalition forces.

Taking into account the statements of the President of Estonia and the information presented by the senior commander of the US Army General Hodges it must be stated that the Suwalki isthmus is a strategically important region on the map of Europe. The occupation of this area would cut off the Baltic States from the remaining NATO allies, and thus enable the immediate seizure of their territory. The map illustrates the possibility of connecting the Kaliningrad Region and the territory of Belarus after seizing the Suwalki Isthmus, thus cutting off the land connection with the Baltic States.

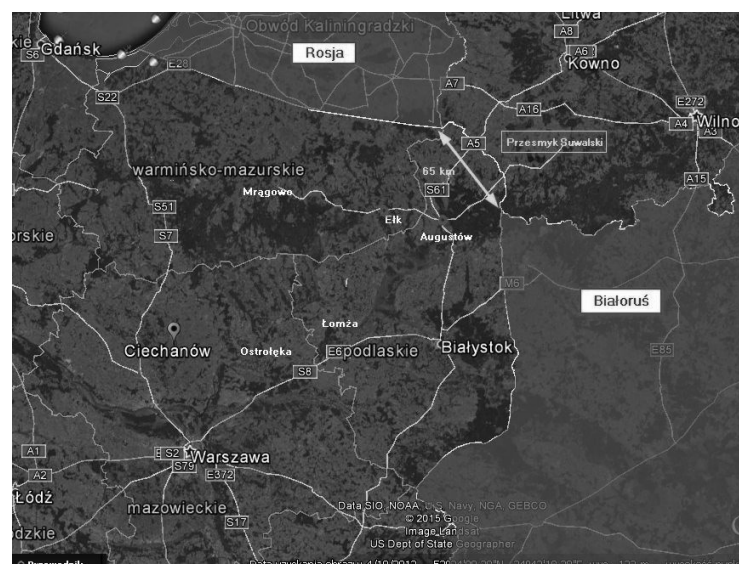

Fig. 1: Suwalki isthmus - one of the three greatest hot spots in Europe

Source: http://www.polskatimes.pl/artykul/9400966, atlanticcouncil-korytarz-suwalski-to-slaby-punkt-nato-rosjanie-moglibypodzielic-sojusz,id,t.html

2 „A jednak! Nasza granica narażona na rosyjską agresję!” Fronda.pl 11.10.2015, retrieved from: http://www.fronda.pl/a/a-jednak-nasza-granicanarazona-na-rosyjska-agresje, $58423 . \mathrm{html}_{2}(02.05 .2017)$. 
When analyzing the Suwalki isthmus defense ability a creation of a new type of forces in Poland should be taken into account ${ }^{3}$, especially of a regional character. The most suitable are Territorial Defense Forces. Suwalki isthmus is an area that is located in two Voivodeships (fig. 2): Podlaskie and Warminsko-Mazurskie, and thus, according to the concept of the TDFs formation, being in the responsibility of two Territorial Defense brigades. TDFs subunits deployment, including their character, capabilities and armaments, should be done in a way that makes the most efficient use of these subunits, thus enabling the tasks to be carried out.

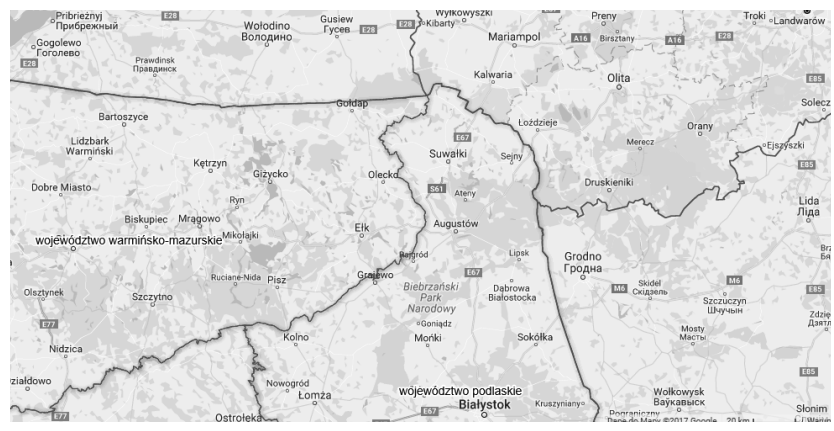

Fig. 2: Suwalki isthmus - territorial division in accordance with the provinces

Source: http://www.mapyonline.pl/

To determine the organization of operations conducted by the air defense forces, including TDFs air defense subunits in the Suwalki isthmus an environment identification and determination of the requirements for air defense assets designated to operate in that region should be carried out.

The purpose of the studies carried out for this article was the identification of the Suwalki isthmus specific environment due to the military operations conduct, as well as determining its influence on organizing and carrying out operations by air defense subunits. To achieve assumed goal the author decided to formulate a research problem in the form of the following question: How does the forest lake environment of the Suwalki isthmus determine organization and operations conduct by air defense subunits? A working hypothesis has been formulated to answer the research question: Specific forest lake environment of the Suwalki isthmus imposes requirements towards air defense forces. It determines the organization of the performed operations, type of the armament and military equipment used, and the significance of the air defense subunits. To verify the assumed hypothesis, an analysis of the literature of the subject was carried out and maps of the region studied.

3 Act of 16 November 2016 amending the Act on the general obligation of defense of the Republic of Poland and certain other acts. Art. 3.

\section{CHARACTERISTICS OF THE SUWALKI INSTHMUS ENVIRONMENT ELEMENTS}

An analysis of the armed conflict experience indicated that one of the main factors determining the success of a conducted operations is a correct assessment of the environmental factors that determine the planning of operations as well as the use of forces and specialist armament. Particularly important is the assessment of the environment conditions when planning the use of air defense subunits. ${ }^{4}$ This is due to the tasks that air defense forces are performing, the need to operate in id various terrains, possibility of using various types of air defense weapons and impact of the environment elements on detecting and interacting with the opponent. Second important aspect of the environmental assessment, when planning air defense operations, is influence on the operations of the enemy's air raid assault means. Varied landform, area covered by vast forests, honeycombed by lakes and watercourses, which are conductive for hidden strikes of the aerial assault means.

Suwalki isthmus is an area located in the Podlaskie and Warminsko-Mazurskie Voivodeships. It is a terrain geographically located in the North-eastern part of Masuria Lake district and more specifically, in the Suwalki, Augustow and Sejny Lake Districts. When analyzing this type of terrain from a military point of view a certain factors should be included:

- the size (area) of forest areas and lakes;

- type of forest and its density;

- hydrographic type of lakes;

- climatic and soil properties;

- degree of the development.

The so-called Suwalki corridor is a region characterized by a considerable forest cover, $30.7 \%$ in the Podlaskie Voivodeship and $31 \%$ in the Warminsko-Mazurskie Voivodeship. (fig. 3). In this area are many forest complexes such as Romnicka, Augustowska, Knyszynska and Bialowieska.

There are numerous lakes typical for lake districts, swamps and various types of watercourses (fig. 4). There are about 250 lakes per hectare in the Suwalki Lake District, most of them are gutter lakes. Moraine and oval lakes characterized by irregular shorelines are also in this area.

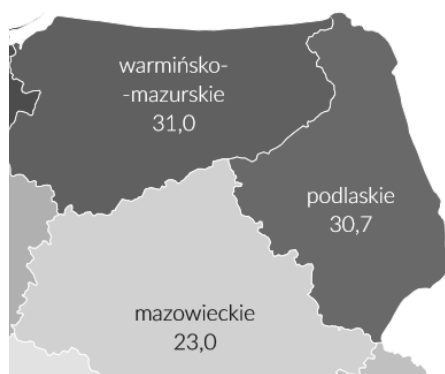

Fig. 3: Forestation in Poland in various voivodeships

Source: Report on the state of forests in Poland in 2013, State Forests, Warsaw 2014

4 See: A. Radomyski, K. Dobija, Air defense in specific environments, AON, Warszawa 2013, p. 7. 


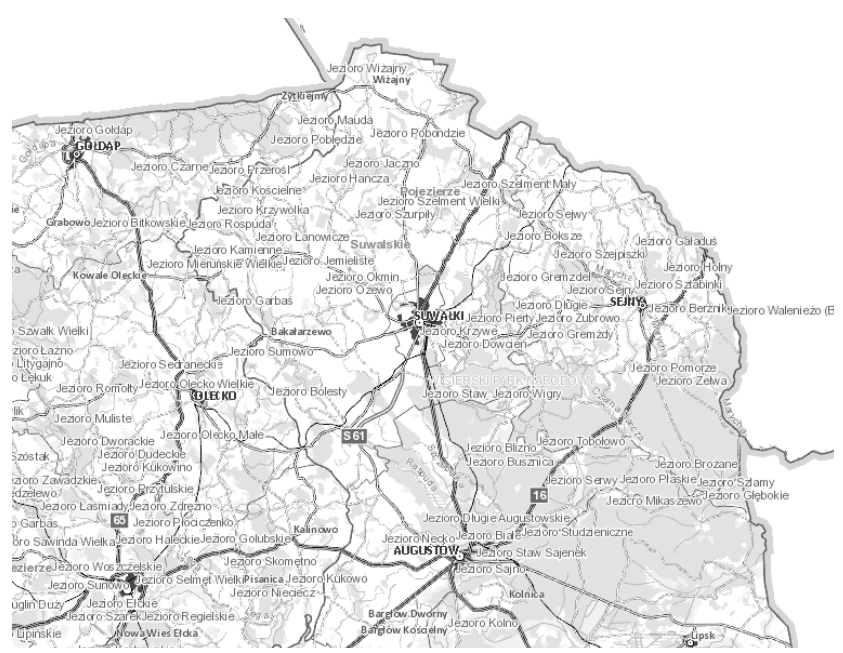

Fig. 4: Lakes in the Suwalki isthmus

Source: http://mapy.geoportal.gov.pl/imap/?gpmap=gp4

The region mainly formed by Baltic glaciation, therefore, it has a typical, young glacial landscape with moraine strips, drumlins ${ }^{5}$, numerous kame hills ${ }^{6}$, and sandur plains. In the formation of the Suwalki isthmus a high altitude differences are characteristic, especially height difference. ${ }^{?}$ The highest moraine hills reach $300 \mathrm{~m}$ ASL. there are also no-flood recesses with peat bogs, gutter (Hancza) and kettle lakes (Wigry).

This region belongs, beyond the mountains, to the coolest areas in the country. The climate is raw and has the most continental features. It is characterized by a low average annual temperature 6 degrees centigrade, early, long and freezing winters with a long lasting cover of snow (about 100 days). Average annual rainfalls are $600 \mathrm{~mm}$.

The main city centers, gathering population in the region are:

- Suwalki 69239 residents;

- Augustow 30616 residents.

By these cities are running main roads through Lithuania and the main railway line linking Poland with Lithuania, Latvia and Estonia.

The character of the studied area has an impact on the enemy's aerial assault means activities and thus on carrying out operations by own air defense subunits, since:

- It limits the range of detection and fire management;

- It limits the choice and quantity of the air defense launching pads;

- It increases masking features of the terrain for the possibility of ambush;

5 Drumlin - it is a low, oval hill (length up to about $1 \mathrm{~km}$, height $5-60$ $\mathrm{m}$ ) with longitudinal, asymmetrical profile (steep slope occurs from the side from which the glacier slides)

6 Kem hill - a form of land surface: hump, hill or hill with a height of several to several meters and a diameter of several hundred meters, conical or flat at the apex and steep slopes.

7 Height difference - a difference in height between the highest and lowest points in a particular area. The term denivelation is used in geography and geology in general for all surface inequalities, aquifers, layers, areas of nonconformity. It generally denotes the morphological differentiation of the surface or its slope. The surface of the devolved or the surface of the denivision is not flat or horizontal.
- it makes maneuvers difficult;

- It makes radio communication difficult;

- hinders orientation in the field;

- it enables operations for a diversionary groups;

- is favorable to the formation of an abatic forest as a result of artillery fire;

- is favorable to fires;

- through limited space and visibility it can exert a negative psychological impact on the soldiers and thus increase earlier psychological and physical exhaustion. ${ }^{8}$ Basing on the analysis of the studied subject matter, the environment of the Suwalki isthmus can be identified and qualified as a forest lake terrain. Therefore, all organization and implementation of the air defense measures in this region should be conducted in accordance with the specific type of the forest lake environment character. Especially considering the three main groups of factors affecting the effectiveness of the air defense, i.e.:

- terrain;

- climate;

- vegetation. $^{9}$

Basing on the factors assessment affecting the forest lake environment and the resulting restrictions it can be stated that the way of a carried out activities by the air defense elements, in the given area should be different from those conducted in a conditions.

\section{ORGANIZATION AND COMMAND OF THE AIR DEFENSE IN A SPECIFIC FOREST-LAKE ENVIRONMENT OF THE SUWALKI ISTHMUS}

The forest-lake area is completely or mostly covered with forests, lakes, waterways and marshes. Conducting operations by the air defense forces in that kind of environment is limited to use, during defense, attack or withdraw, only roads, sheds and isthmus between lakes. By carrying out actions in such an environment, it is necessary to assume the possibility of operating in isolation from the groupings of own forces. Subunits performing tasks should be prepared for self-operation in a particular army grouping. In the forest-lake environment there is a possibility of fragmentation of some air defense forces and means, simultaneously maintaining the main effort resulting from the tasks received. ${ }^{10}$

An important element in the organization of operations in the woodland environment is to consider a specific, different than in normal conditions, effects of the use of weapons of mass destruction and combat gases that have impact on:

- longer durability of poisonous gases;

- extensive spatial fires as a result of thermal radiation;

8 See: Rules of the combat air defense subunits. Battery, platoon, team (service), Land Forces Command, Air defense Headquarters, Warsaw 2000, p. 163.

9 See: A. Radomyski, K. Dobija, Air defense in specific environments, AON, Warszawa 2013, p. 16.

10 See. A. Radomyski, K. Dobija, Air defense in specific environments, AON, Warszawa 2013, p. 60. 
- obstacles in deployment as a result of the abatic forest under impact of a shock wave. ${ }^{11}$

Assuming the use of the WMD by the opponent in the area there should be planned escape, fire routes and alternative ways to withdraw troops from the affected area.

Another important determinant of the effective air defense conduct is the assessment of the enemy's aerial assault means attacks. Suwalki isthmus area (forest lake area) creates favorable conditions for use of the aerial assault means, and in particular combat helicopters. This is related to the possibility of a hidden approach (organization of ambushes conducted by helicopter) and the difficulty of maintaining the continuity of the defense line, and air defense zones. This is also due to the limited capacity for action great groups of ground units in the area crossed by lakes, rivers, swamps and forests. The enemy's aerial assault means will focus their effort mainly on striking on subunits defending the key directions of attacks, located mainly on the isthmus between lakes. The targets of the combat helicopters strikes can also be:

- command posts;

- artillery positions;

- bridges;

- service support positions;

- radiolocation posts;

- communication nodes.

Organization of the air defense in specific environments has necessarily deal with the requirements, which are imposed on launching pads of a particular missile systems as well as their tactical and technical specification. Fire positions of the air defense subunits should be located at the edge of the forest, along the roads, clearings, woodlets and other locations enabling a complete use of the given air defense armament. One of the air defense missile systems which Polish Army is equipped with is PZR 2K12 "KUB". Figure 5 presents $2 \mathrm{~K} 12$ system on a launching pad. An area of the air defense battery combat grouping should provide the maximum use of fire capabilities in order to inflict loses for the enemy's aerial means and is characterized by features enlisted below:

- even surface $300 \times 300 \mathrm{~m}$;

- elevation of the surveillance radar towards missile launcher should not exceed $1,5^{\circ}$;

- sector of the air defense battery angels of cover should be close to 0 (should not exceed $30^{\circ}$ );

- heighness of the terrain objects in the distance of $100 \mathrm{~m}$ from the missile launcher should not exceed $20 \mathrm{~m}$;

- the angle of surface inclination, where missile launcher is located should not exceed $4^{\circ}$;

In the radius of $100 \mathrm{~m}$ from missile launcher there should not be any stones, aggregates, bricks and another objects, which could injure operators or equipment.

11 See: The use of smoke in the combat conditions. Guidance, Land Forces Command, Headquarters of the Military CBRN Defense, Warsaw 2001, p. 30 .

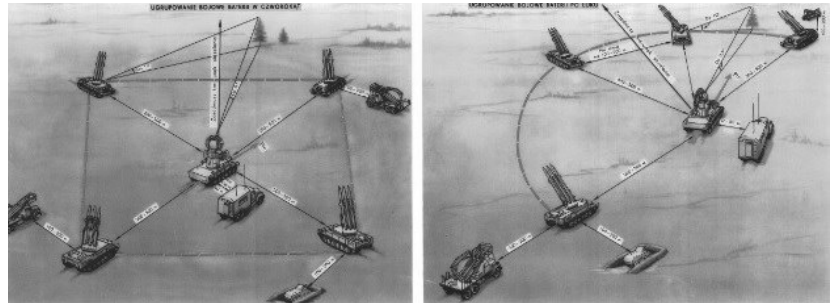

Fig. 5: Combat grouping of $2 \mathrm{~K} 12$ system (in a square and by the arc) Source: Presentation boards of the 2 K12 KUB systems

Another air defense system used in the Polish Armed Forces is PZR NEWA, which requirements towards fire positions and infrastructure needed to operate the system are as followed: ${ }^{12}$

- Even surface 200x200m;

- small angels of cover;

- necessity of creating hides for soldiers;

- high bearing capacity of roads and bridges;

- developed communication infrastructure (large size of radars directing missiles).

Analyzing requirements for the launching pad of the KUB and NEWA systems and taking into account the tactical features of operation (for example designating alter launching pads at suitable distances), it should be stated that the use of these systems, on the lake-forest area altogether with making these systems capabilities fully operational is in a great matter a difficulty. The air defense missile system having less limits to provide air defense cover in a forest-lake terrain is an air defense subunit OSA. This is due to the capabilities of PRWB OSA:

- detection, recognition and engagement of targets by a single vehicle;

- overcoming water obstacles (amphibious vehicle);

- conducting recognition during march.

By planning air defense in the studied area, KUB and OSA systems should be displaced in the first stage (systems operating in the Land Forces structures), and the resulting gaps, due to the terrain limitations, fill with subunits equipped with portable missile systems GROM, self-propelled air defense systems (SZYLKA, HIBNERYT) and air defense cannons.

Presented organization of the air defense forces will ensure the continuity of the line of air defense cover of the designated area in the forest-lake area.

Forest-lake battlefield, to which we can qualify Suwalki isthmus, imposes towards air defense forces a number of constraints and challenges. Restrictions, resulting from the character and method of the air assault means operation, defines requirements for the air defense subunits, armament and air defense equipment in order to provide efficient air defense cover for forces. Air defense forces conducting operations in the forest-lake environment should be equipped with military gear characterized by: ${ }^{13}$

12 See. http://infowsparcie.net/wria/o_autorze/pzr_s125m.html, [access: 28th May, 2017]

13 See: J. Pająk, ,Środki lekkiej obrony przeciwlotniczej w osłonie pododdziałów wojsk lądowych”, Zeszyty Naukowe WSOWL 3(153), 2009. 
- high mobility and maneuverability;

- ability to provide own fire;

- ability to operate with a different military equipment;

- resistance to various types of interference;

- ability to operate in different organizational structures;

- short time needed for fire assets reaction.

Significance of the studied Suwalki isthmus and its specific character of the environment forces to find and include light, mobile, units being able to carry out operations in various conditions of the battlefield as far as air defense is concerned. Armament having such features is qualified, as a light air defense assets. ${ }^{14}$ An example of the light air defense assets is Bundeshwera combat vehicle OZELOT its export version is ASRAD (Drawing 6), (Atlas Short-Range Air Defense System).

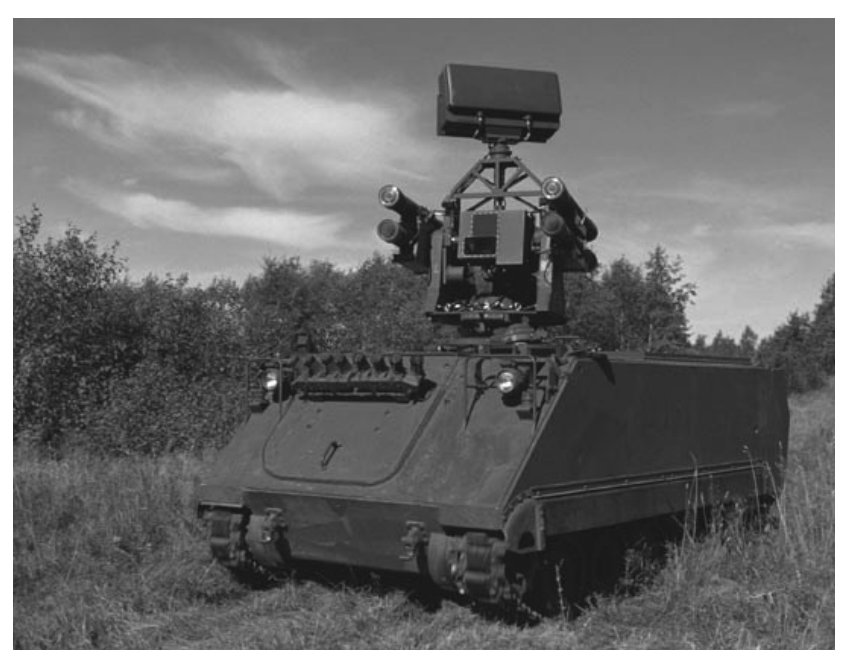

Fig. 6: The ASRAD-R with Bolide missile and the HARD 3D search radar

Source: http://www.army-technology.com/projects/leflasys/ leflasys $8 . h t m l$

Polish light air defense assets are self-propelled air defense missile systems POPRAD (Fig. 7). It should be stated that this system, thanks to its capabilities: ${ }^{15}$

- operates autonomously;

- can be installed on various platforms;

- operates during day and night conditions;

- operates in various structures;

- is characterized by high mobility;

- difficult to be detected for the opponent.

- can effectively carry out air defense in the analyzed environment of the Suwalki isthmus.

14 J. Pająk, „Środki lekkiej obrony przeciwlotniczej w osłonie pododdziałów wojsk lądowych", Zeszyty Naukowe WSOWL 3(153), 2009. p. 35 15 M. Dura, „Zestaw przeciwlotniczy Poprad i jego miejsce w Tarczy Polski”, Defence24 20.03.2015, retrieved from: www.defense24. p1/206324,zestaw-przeciwlotniczy-poprad-i-jego-miejsce-w-tarczy-polski, (08.05.2017)

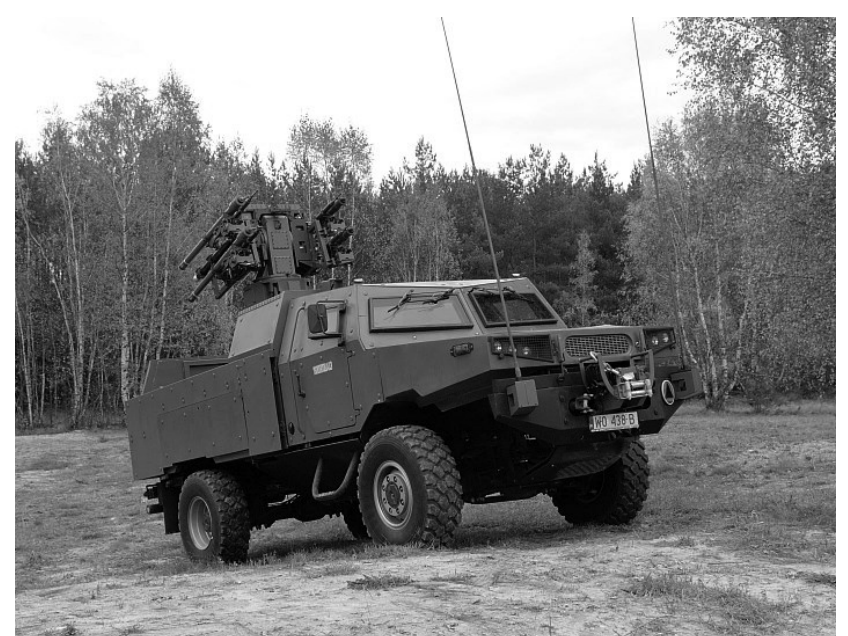

Fig. 7: SPZR POPRAD

Source: http://www.pitradwar.com/oferta/zestawy-przeciwlotnicze /systemy-obrony-przeciwlotniczej/poprad/

\section{CONCLUSION}

The nature of the environment should be taken into account when planning military action. Basing on the literature analysis of the subject, it can be stated that the nature of the battlefield will be determined by:

- type of armament and military equipment used in the operations;

- maneuverability of troops;

- the way of organizing operations carried out by own and enemy forces;

- the meaning and operations conducted by aerial assault means;

- time needed for detecting the aerial assault means and fire response;

- influence on the mental and physical resistance of the soldiers;

- service support.

Basing on the analysis of the forest-lake environment of the Suwalki isthmus it can be assumed that in order to control this region the main course will be focused on aerial assault means, due to the low capacity and patency of this area. The use of aerial assault forces in seizing Suwalki isthmus means the increased significance of the air defense, in providing air defense cover for forces as well as critical infrastructure.

The analysis of the Suwalki isthmus including identification of the environment, impact of the specific area in the forest-lake environment, on military operations and juxtaposition effective air defense with the requirements of armament and military equipment, allow to define the requirements of the air defense subunits. Field conditions and probable character of operation aerial assault means in the Suwalki Isthmus force the need to adapt air defense forces to the theater of action. It seems appropriate to use light air defense assets to carry out air defense tasks for the troops and objects of the isthmus. The concept of using air defense light forces is justified because it meets the requirements of the forest-lake environment of the region 
and provides effective counteracting of the threats created by aerial assault means. By planning air defense operations in the region it is right and to determine where the air defense elements of the TDFs should be included. This is related to the need to ensure the continuity of the defense of the critical infrastructure of the area as well as the fact of selecting and purchasing air defense means for the TDFs subunits.

\section{BIBLIOGRAPHY}

1. Act from November $16^{\text {th }}, 2016 \mathrm{r}$. amending the act of the general obligation of Republic of Poland defense and other acts. Article 3, point 3.

2. Dowództwo Wojsk Lądowych, Szefostwo Wojsk Obrony Przeciwchemicznej Użycie dymów w warunkach bojowych. Poradnik, Warszawa 2001.

3. Dowództwo Wojsk Lądowych, Szefostwo Wojsk Obrony Przeciwlotniczej, Regulamin walki pododdziałów przeciwlotniczych. Bateria, pluton, dziaton/drużyna (obstuga), Warszawa 2000.

4. Fronda.pl.,Ajednak! Nasza granica narażona na rosyjska agresję! Fronda.pl 11.10.2015, retrieved from: http:// www.fronda.pl/a/a-jednak-nasza-granica-narazona-narosyjska-agresje,58423.html, (02.05.2017).

5. Pająk, J., Lekka obrona przeciwlotnicza wobec zagrożeń powietrznych, Zeszyty Naukowe WSOWL 3(149), 2008. 42-54.

6. Pająk, J., Środki lekkiej obrony przeciwlotniczej w osłonie pododdziałów wojsk laddowych, Zeszyty Naukowe WSOWL 3(153), 2009. 29-38.

7. Rachoń, M., NATO ostrzega: Polska najbardziej zagrożonym rejonem po Donbasie, Niezależna.pl 09.10.2015, retrieved from: http://niezalezna.pl/71738nato-ostrzega-polska-najbardziej-zagrozonymrejonem-po-donbasie, (02.05.2017).

8. Radomyski, A., Dobija, K., Obrona przeciwlotnicza w specyficznych środowiskach, NUD, Warszawa 2013.

9. Zajączkowski, G., Jabłoński, M., Raport o stanie lasów w Polsce w 2013r., Lasy Państwowe, Warszawa 2014.

10. Dura, M., Zestaw przeciwlotniczy Poprad i jego miejsce w Tarczy Polski, Defence 24 20.03.2015, retrieved from: www.defense24.pl/206324,zestaw-przeciwlotniczypoprad-i-jego-miejsce-w-tarczy-polski, (08.05.2017). 